\title{
Systematic review of insulin-like growth factor 1 gene expression in women with breast cancer
}

\author{
Danylo Rafhael Costa-Silva' (1D, Maria da Conceição Barros-Oliveira (1), \\ Benedito Borges da Silva ${ }^{1 *}$
}

\section{INTRODUCTION}

Cancer incidence and mortality are rapidly growing worldwide, representing a serious global health problem ${ }^{1}$. Breast cancer is the most frequently diagnosed malignant neoplasm in the majority of countries and is the leading cause of cancer death among women ${ }^{2}$. In the year 2018, approximately 2.1 million new cases of breast cancer were estimated to occur worldwide ${ }^{3}$. Breast cancer is a complex disease of unknown and multifactorial etiology, in which one of the main risk factors is genetic alteration ${ }^{4,5}$. Thus, genetic mutations of breast cancer (BRCA) 1 and 2 genes are related to the increased risk of hereditary breast and ovarian cancer over time ${ }^{6}$; however, the participation of genes in breast cancer has not yet been fully elucidated ${ }^{4,5}$. Thus, changes in expression levels of the insulin-like growth factor 1 (IGF-1) gene have been evaluated in breast cancer; however, there is a need for further elucidation of the association between changes in IGF-1 levels and increase in the risk, survival, and disease progression of breast cancer ${ }^{7}$.

The IGF system consists of two peptidic hormones (IGF-1 and IGF-2), two cell surface receptors (IGF-1R and IGF-2R), and at least six IGF-binding proteins (IGFBP 1-6) that control normal growth and differentiation in most of the tissues ${ }^{8}$. In combination with the growth hormone, insulin, and sex hormones, IGF-1 acts as a crucial regulator of cell growth, differentiation, and apoptosis, as it has striking mitogenic and antiapoptotic activities in cancer cells, acting synergistically with estrogen to promote tumor growth ${ }^{9}$. Epidemiological and experimental evidence attempted to clarify the role of the IGF-1 axis in human breast cancer and showed controversial results. While some studies indicated that increased levels of IGF-1 gene expression are associated with a better prognosis in breast cancer ${ }^{10}$, other authors have suggested that increased levels of IGF-1 gene expression could be associated with increased cell proliferation in breast cancer ${ }^{11,12}$. Thus, altered levels of IGF-1 gene expression may be related to better prognosis or unfavorable outcomes and greater aggressiveness in breast can$\operatorname{cer}^{13,14}$. However, there is a scarcity of studies on this subject in women with breast cancer. This motivated us to detail, in a systematic review, the available studies in the databases to investigate the influence of IGF-1 gene expression levels in women with breast cancer.

\section{METHODS}

\section{Search strategy}

This study was carried out using the PubMed, Scopus, and Web of Science databases. Searches were conducted between February 2, 2019, and May 15, 2019. The search strategy included the crossing of the following descriptors: "breast cancer" OR "breast neoplasm" AND "IGF-1" AND "gene"; "breast cancer" OR "breast neoplasm" AND "IGF-1" AND "expression"; "breast cancer" OR "breast neoplasm" AND "IGF-1" AND "mRNA"; "breast cancer" OR "breast neoplasm" AND "IGF-1" AND "gene" AND "expression."

\section{Study selection and eligibility criteria}

A collection of eligibility criteria was used to select articles from the literature. Inclusion criteria were studies published between 2009 and 2019, English language publications, and human studies addressing the gene expression of IGF-1 in breast cancer. Exclusion criteria were duplicate articles, articles with only abstracts available, literature reviews, editorials, letters to the editor, conference proceedings, and articles related to breast cancer and IGF-1 that did not quantitatively analyze the levels of gene expression.

'Universidade Federal do Piauí, Rede Nordeste de Biotecnologia - Teresina (PI), Brazil.

*Corresponding author: beneditoborges@globo.com

Conflicts of interest: the authors declare there is no conflicts of interest. Funding: none.

Received on February 28, 2021. Accepted on March 21, 2021. 


\section{Data extraction and quality assessment}

All identified studies were independently reviewed by two authors for the relevance of the inclusion/exclusion criteria. After a primary examination, all the complete studies retrieved were subjected to a more detailed evaluation and were compared and verified to ensure equivalence in the selection and analysis of articles. The selection process of the studies was mapped according to the preferred reporting items for systematic reviews and meta-analyses (PRISMA) guidelines ${ }^{10}$.

\section{RESULTS}

A total of 2,370 studies were identified through PubMed databases ( $n=749)$, Scopus ( $n=330)$, and Web of Science $(n=1,291)$. After selecting and applying the inclusion and exclusion criteria, five articles were included in the present systematic review, according to the flow chart detailing the process of identification, selection, eligibility, and final inclusion of the studies (Figure 1). The description of the selected studies is shown in Table 1.

The association between IGF-1 mRNA expression levels in tumor tissues of women with breast cancer and the characteristics of the disease was examined by Mu et al. ${ }^{15}$. A significant association was found between increased levels of IGF-1 mRNA expression and small tumors $(<2 \mathrm{~cm})$, low-grade tumors, and

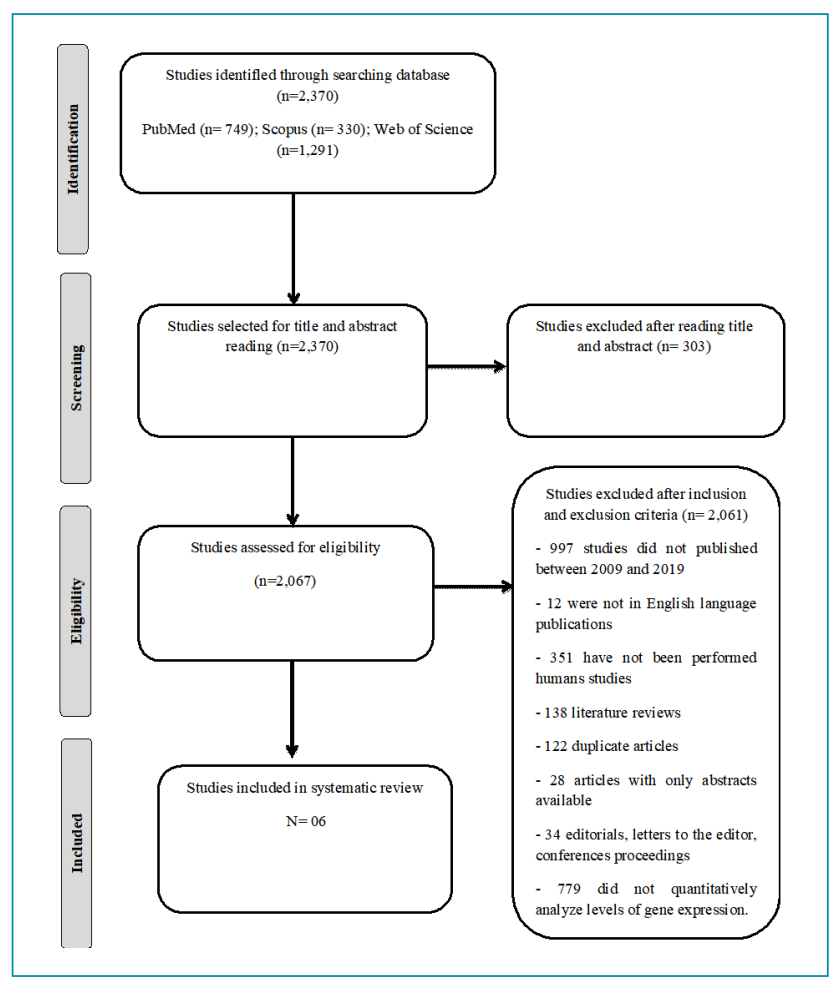

Figure 1. Flowchart detailing the process of identification, selection, eligibility, and final inclusion of the studies. estrogen receptor (ER)- or progesterone receptor (PR)-positive tumors. The survival analysis showed that women with high IGF-1 mRNA expression had a lower risk of disease recurrence and death compared to those with low expression.

In another study, Mu et al..$^{13}$ showed that increased levels of IGF-1 mRNA expression were associated with the luminal subtype A, normal-like, and less aggressive tumors (ER-positive, lowgrade, and node-negative tumors). However, decreased levels of IGF-1 mRNA expression were associated with the basal, human epidermal growth factor receptor 2 (HER2), and luminal B subtypes. Thus, the results of their studies showed an inverse association between IGF-1 mRNA levels and the prognosis of the disease.

Chong et al. ${ }^{11}$ analyzed the relationship between IGF-1 mRNA expression levels in breast tumors and adjunctive normal tissues (TNAs) and the clinicopathological and prognostic factors of women with breast cancer. No correlation was observed in tumor tissue and TNAs between IGF-1 mRNA expression levels and clinicopathological factors such as histological grade, lymph node status, and tumor size; however, increased levels in tumor tissue and TNAs were associated with increased disease-free survival (DFS).

Raval and Trivedi ${ }^{7}$ studied the levels of IGF-1 mRNA expression in TNAs of women undergoing mastectomy for breast cancer treatment. Significantly, the lower levels of IGF-1 mRNA expression were observed in the breast tumors, regardless of age, menopausal status, tumor size, lymph node status, and histological stage when compared with those in the TNAs. On the other hand, in this study, the low expression was associated with more advanced stages. Thus, a significant inverse correlation was observed between stage, histological type, and levels of IGF-1 mRNA expression.

Christodoulou et al. ${ }^{12}$ analyzed the in-tumor expression of IGF-1 mRNA in patients with trastuzumab-treated HER2positive metastatic breast cancer and showed that IGF-1 mRNA expression levels were higher in patients over the age of 50 years at the time of the initial diagnosis and absence of bone metastases. In contrast, decreased levels were associated with histological grade III, distal, and mainly visceral metastases. Chong et al. ${ }^{16}$ showed that tumors with high levels of IGF-1 mRNA expression were associated with a significantly longer time to develop resistance to tamoxifen.

\section{DISCUSSION}

The studies evaluated in this systematic review have shown controversial results related to the levels of IGF-1 gene expression in women with breast cancer. Mu et al. ${ }^{15}$ showed that elevated IGF-1 mRNA expression was associated with indicators of good prognosis. These results agree with previous studies that showed that elevated levels of IGF-1 mRNA were associated 
Table 1. Description of the selected studies.

\begin{tabular}{|c|c|c|c|c|}
\hline Author & $\begin{array}{l}\text { Type of } \\
\text { study }\end{array}$ & $\begin{array}{l}\text { Characteristic } \\
\text { population }\end{array}$ & Sample size & Conclusion \\
\hline $\begin{array}{l}\text { Mu et al. }{ }^{15}, \\
2009\end{array}$ & Cohort & $\begin{array}{l}\text { Italian } \\
\text { women }\end{array}$ & $\begin{array}{l}204 \text { cases of } \\
\text { breast cancer }\end{array}$ & $\begin{array}{l}\text { High levels of IGF-1 mRNA expression were associated } \\
\text { with small tumors, earlier stages of the disease, low-grade } \\
\text { tumors, ER- or PR-positive tumors, and a better prognosis. }\end{array}$ \\
\hline $\begin{array}{l}\text { Mu et al. }{ }^{13}, \\
2012\end{array}$ & Cohort & $\begin{array}{l}\text { Italian } \\
\text { women }\end{array}$ & $\begin{array}{l}204 \text { cases of } \\
\text { breast cancer }\end{array}$ & $\begin{array}{c}\text { High levels of IGF-1 mRNA expression were associated } \\
\text { with the luminal A and normal-like subtype, with less } \\
\text { aggressive tumors and a better prognosis. }\end{array}$ \\
\hline $\begin{array}{l}\text { Chong } \\
\text { et al. }{ }^{11}, 2011\end{array}$ & Cohort & $\begin{array}{l}\text { English } \\
\text { women }\end{array}$ & $\begin{array}{l}132 \text { cases of } \\
\text { breast cancer }\end{array}$ & $\begin{array}{l}\text { IGF-1 mRNA levels did not correlate with clinic } \\
\text { pathological factors. However, increased levels of IGF- } \\
1 \text { mRNA expression were associated with higher DFS. }\end{array}$ \\
\hline $\begin{array}{l}\text { Raval and } \\
\text { Trivedi }, 2016\end{array}$ & Cohort & $\begin{array}{l}\text { Indian } \\
\text { women }\end{array}$ & $\begin{array}{l}106 \text { cases of } \\
\text { breast cancer }\end{array}$ & $\begin{array}{l}\text { Significantly lower levels of IGF-1 mRNA expression were } \\
\text { observed in breast tumors regardless of age, menopausal } \\
\text { status, tumor size, lymph node status, and histologic } \\
\text { grade. There were no associations with OS and DFS. }\end{array}$ \\
\hline $\begin{array}{l}\text { Christodoulou } \\
\text { et al. } .^{12}, 2018\end{array}$ & Cohort & $\begin{array}{l}\text { Greek } \\
\text { women }\end{array}$ & $\begin{array}{l}227 \text { cases of } \\
\text { breast cancer }\end{array}$ & $\begin{array}{l}\text { High levels of IGF-1 mRNA expression were associated } \\
\text { with older age and absence of bone metastases. } \\
\text { Already decreased levels of expression were associated } \\
\text { with histological grade III and metastases. }\end{array}$ \\
\hline $\begin{array}{l}\text { Chong } \\
\text { et al. }{ }^{16}, 2011\end{array}$ & Cohort & $\begin{array}{l}\text { English } \\
\text { women }\end{array}$ & $\begin{array}{l}92 \text { cases of } \\
\text { breast cancer }\end{array}$ & $\begin{array}{l}\text { High levels of IGF-1 mRNA expression were associated } \\
\text { with delay in developing resistance to tamoxifen. } \\
\text { Decreased levels of IGF-1 mRNA expression were } \\
\text { associated with tamoxifen-resistant tumors. }\end{array}$ \\
\hline
\end{tabular}

ER: estrogen receptor; PR: progesterone receptor; DFS: disease-free survival; OS: overall survival.

with better prognosis of the disease ${ }^{17}$. Mu et al. ${ }^{15}$ suggested that high-grade tumors that invade adjacent tissues or spread to distant organs may become less dependent on IGF-1 regulation and that small and low-grade tumors respond well to IGF-1 signals, while in another study, they showed that increased levels of IGF-1 mRNA expression were associated with luminal $A$ and normal-like subtypes.

In a study by Chong et al. ${ }^{11}$, even though correlation was not observed between IGF-1 mRNA expression levels and clinicopathological factors such as histological grade, lymph node status, and tumor size, increased levels of IGF-1 mRNA expression in tumor tissue and TNAs were found to be associated with higher DFS, and this was statistically independent of other clinicopathological features ${ }^{11}$. These findings agree with previous studies where high IGF-1 mRNA expression was established as an independent predictor of higher DFS and $\mathrm{OS}^{17}$ and suggesting that the IGF-1 gene may increase cell differentiation in certain types of cancer, and this would be associated with less aggressive cancers and consequently with better prognosis.

Raval and Trivedi ${ }^{7}$ showed significantly lower levels of IGF-1 mRNA expression in breast tumors in women compared with those in TNAs. These findings suggesting the existence of a paracrine relation within the local environment of the cancerous mammary tissue, where the expression may differ according to the type of cell present within the tissues, and the greater expression of IGF-1 in TNAs would stimulate cell proliferation and inhibit apoptosis, causing the levels to be high in TNAs and low in breast tumors ${ }^{7}$.

The findings of Christodoulou et al. ${ }^{12}$ in women with HER2positive breast cancer treated with trastuzumab showed elevated levels of IGF-1 mRNA expression in women older than 50 years at the time of diagnosis and absence of bone metastases. On the contrary, decreased levels of IGF-1 mRNA expression were found in patients with histological grade III and visceral distal metastases, which may be justified by the fact that IGF-1 could be involved in the mechanism of resistance to treatment with trastuzumab ${ }^{18}$, suggesting that cross-communication of IGF-1/HER2 may occur via autocrine and/or paracrine signaling in breast cancer ${ }^{18}$. Chong et al. ${ }^{16}$ has shown that higher levels of IGF-1 mRNA expression are associated with lower tamoxifen resistance in breast cancer. Some studies have shown that resistance to tamoxifen may be due to altered downstream cellular pathways involving IGF- ${ }^{19}$. However, patients with tamoxifen-sensitive breast cancer had not yet used the drug at the time of the biopsy and were under estrogenic stimulation, which could explain the higher levels of IGF-1 mRNA in these patients, unlike breast cancers resistant to tamoxifen that become independent of estrogen stimulation, and as IGF-1 
tends to correlate with estrogen, this may justify low levels of IGF-1 mRNA in these tumors ${ }^{16}$. A probable explanation for conflicting results found among the authors is due to the limitations of the studies evaluated, especially lack of standardization in the methodology, where different protocols of gene expression analysis were used, and heterogeneous samples with relatively small sample numbers and with different ethnicities.

\section{CONCLUSIONS}

This systematic review provides evidence that increased or decreased levels of IGF-1 gene expression may be associated with clinicopathological aspects of breast cancer, DFS, OS, and resistance to tamoxifen in women with breast cancer. However, there is a shortage of studies on the subject, mainly with larger samples, in Latin American women with recurrence of breast cancer. Therefore, the elucidation of IGF-1 gene expression patterns through further studies may allow the characterization of women at high risk for breast cancer, as well as the development of strategies for prognosis and effective treatment, allowing better survival and reduction of progression of the disease.

\section{ACKNOWLEDGMENT}

The authors thank the RENORBIO.

\section{AUTHORS' CONTRIBUTIONS}

DRCS: Conceptualization and design of the study, search and analysis of articles, writing of the original manuscript, and elaboration and revision of the graphic components (tables and figures). MCBO: study design, search, and analysis of articles, writing of the original manuscript, and elaboration and revision of graphic components (tables and figures). BBS: conceptualization and design of the study, revision and orientation of methodology, revision of graphic components (tables and figures), and revision of the original and final manuscripts.

\section{REFERENCES}

1. Limonta P, Moretti RM, Marzagalli M, Fontana F, Raimondi $\mathrm{M}$, Marelli MM. Role of endoplasmic reticulum stress in the anticancer activity of natural compounds. Int J Mol Sci. 2019;20(4):961. https://doi.org/10.3390/ijms20040961

2. Bray F, Ferlay J, Soerjomataram I, Siegel RL, Torre LA, Jemal A. Global cancer statistics 2018: GLOBOCAN estimates of incidence and mortality worldwide for 36 cancers in 185 countries. CA Cancer J Clin. 2018;68(6):394-424. https:// doi.org/10.3322/caac.21492

3. Ferlay J, Colombet M, Soerjomataram I, Mathers C, Parkin DM, Piñeros $M$, et al. Estimating the global cancer incidence and mortality in 2018: GLOBOCAN sources and methods. Int J Cancer. 2019;144(8):1941-53. https://doi.org/10.1002/ ijc.31937

4. Costa-Silva DR, Barros-Oliveira MC, Borges RS, CamposVerdes LM, da Silva-Sampaio JP, Escorcio-Dourado CS, et al. Insulin-like growth factor 1 gene polymorphism in women with breast cancer. Med Oncol. 2017;34(4):59. https://doi. org/10.1007/s12032-017-0915-4

5. Campos-Verdes LM, da Silva-Sampaio JP, Costa-Silva DR, de Oliveira VA, Conde Junior AM, Silva VC, et al. Genetic polymorphism of calcium-sensing receptor in women with breast cancer. Med Oncol. 2018;35(3):23. https://doi.org/10.1007/ s12032-018-1089-4

6. Abu-Helalah M, Azab B, Mubaidin R, Ali D, Jafar H, Alshraideh $\mathrm{H}$, et al. BRCA1 and BRCA2 genes mutations among high risk breast cancer patients in Jordan. Sci Rep. 2020;10(1):17573. https://doi.org/10.1038/s41598-020-74250-2

7. Raval A, Trivedi S. Breast cancer: role of IGF-1 and IGFBP-3 expression in prognostication. Indian J Exp Biol. 2016;54(10):61929. PMID: 30084561
8. Cevenini A, Orrù S, Mancini A, Alfieri A, Buono P, Imperlini $E$. Molecular signatures of the insulin-like growth factor 1-mediated epithelial-mesenchymal transition in breast, lung and gastric cancers. Int J Mol Sci. 2018;19(8):2411. https:// doi.org/10.3390/ijms19082411

9. Ipsa E, Cruzat VF, Kagize JN, Yovich JL, Keane KN. Growth hormone and insulin-like growth factor action in reproductive tissues. Front Endocrinol (Lausanne). 2019;10:777. https:// doi.org/10.3389/fendo.2019.00777

10. Moher D, Liberati A, Tetzlaff J, Altman DG, PRISMA Group. Preferred reporting items for systematic reviews and metaanalyses: the PRISMA statement. BMJ. 2009;339:b2535. https://doi.org/10.1136/bmj.b2535

11. Chong KYM, Subramanian A, Mokbel K, Sharma AK. The prognostic significance of the insulin-like growth factor-1 ligand and receptor expression in breast cancer tissue. J Surg Oncol. 2011;104(3):228-35. https://doi.org/10.1002/jso.21916

12. Christodoulou C, Oikonomopoulos G, Koliou GA, Kostopoulos I, Kotoula $\mathrm{V}$, Bobos $\mathrm{M}$, et al. Evaluation of the insulin-like growth factor receptor pathway in patients with advanced breast cancer treated with trastuzumab. Cancer Genomics Proteomics. 2018;15(6):461-71. https://doi.org/10.21873/ cgp.20105

13. Mu L, Tuck D, Katsaros D, Lu L, Schulz V, Perincheri S, et al. Favorable outcome associated with an IGF-1 ligand signature in breast cancer. Breast Cancer Res Treat. 2012;133(1):321-31. https://doi.org/10.1007/s10549-012-1952-5

14. De Santi M, Annibalini G, Barbieri E, Villarini A, Vallorani L, Contarelli S, et al. Human IGF1 pro-forms induce breast cancer cell proliferation via the IGF1 receptor. Cell Oncol (Dordr). 
2016;39(2):149-59. https://doi.org/10.1007/s13402-0150263-3

15. $M u$ L, Katsaros $D$, Wiley $A$, Lu L, de la Longrais IAR, Smith $S$, et al. Peptide concentrations and mRNA expression of IGF-I, IGF-II and IGFBP-3 in breast cancer and their associations with disease characteristics. Breast Cancer Res Treat. 2009;115(1):151-62. https://doi.org/10.1007/s10549008-0046-x

16. Chong K, Subramanian A, Sharma A, Mokbel K. Measuring IGF-1, ER- $\alpha$ and EGFR expression can predict tamoxifenresistance in ER-positive breast cancer. Anticancer Res. 2011;31(1):23-32. PMID: 21273576
17. Haffner MC, Petridou B, Peyrat JP, Révillion F, Müller-Holzner E, Daxenbichler G, et al. Favorable prognostic value of SOCS2 and IGF-I in breast cancer. BMC Cancer. 2007;7:136. https:// doi.org/10.1186/1471-2407-7-136

18. Hartog H, Van Der Graaf WTA, Boezen HM, Wesseling J. Treatment of breast cancer cells by IGF1R tyrosine kinase inhibitor combined with conventional systemic drugs. Anticancer Res. 2012;32(4):1309-18. PMID: 22493363

19. Hua H, Kong Q, Yin J, Zhang J, Jiang Y. Insulin-like growth factor receptor signaling in tumorigenesis and drug resistance: a challenge for cancer therapy. J Hematol Oncol. 2020;13(1):64. https://doi.org/10.1186/s13045-020-00904-3 